Brit. J. vener. Dis. (1960), 36, 118.

\title{
PSYCHOLOGICAL PATTERN OF PATIENTS WITH NON-GONOCOCCAL URETHRITIS*
}

BY

\author{
A. SIBOULET \\ Paris
}

In recent years the problem of infectious urethritis has changed considerably. Gonorrhoea can be cured in a matter of hours or days in the antibiotic era, and this has made more evident the other forms of urethritis in which diagnosis and cure are more difficult. Many cases of non-gonococcal urethritis (N.G.U.) carry with them a heavy train of social consequences. The I.U.V.D.T. has concerned itself with this problem at recent meetings.

Certain features of N.G.U. are characteristic: the onset, the varied aetiology and clinical expression, the course, frequency of relapse, and the rather poor response to treatment. These features provoke a peculiar psychological pattern which is common to patients affected by such types of urethritis.

(1) Onset.-The length of the incubation period is often difficult to estimate, and varies with each type of urethritis. In viral urethritis, the incubation period may vary from a few days to a few weeks (50 to 100 days or more). In cases of urethral infestation with Trichomonas vaginalis, the incubation period varies from 2 to 40 days. In other cases urethritis may develop rather unexpectedly, associated with conjunctivitis, arthritis, or dysentery, and so presents a problem that neither the patient nor the physician is able to solve.

(2) Aetiology.-The improvement of research techniques using special staining methods, cultures, and serological tests, has made it possible to determine the cause in certain types of N.G.U. For example, the recent achievement of Collier (1959) and Jones, Collier, and Smith (1959) in the isolation of the virus of inclusion blennorrhoea is particularly valuable. These investigations, however, are time-consuming in most cases; they require repeated examination of urethral discharge, prostatic fluid and urine, attendance at special clinics, and a careful search for local foci. On this point, the technique of urethral cine-roentgeno-

* Paper read to the General Assembly of the I.U.V.D.T. in London on October 14, 1959. graphy with a brilliancy amplifier after previous roentgentelevision centring, which we apply with Noix, has given quite useful information.

In many cases an aetiological factor is to be found, but sometimes the diagnosis has to be based on routine examination of the contacts or of both partners.

Table 1 shows the causes in 500 cases of N.G.U.

TABLE I

\begin{tabular}{|c|c|c|c|c|c|c|c|}
\hline \multirow{2}{*}{\multicolumn{6}{|c|}{ Aetiology }} & \multicolumn{2}{|c|}{ Cases } \\
\hline & & & & & & \multirow{2}{*}{$\begin{array}{r}\text { No. } \\
86\end{array}$} & \multirow{2}{*}{$\frac{\text { Per cent. }}{17 \cdot 2}$} \\
\hline Bacteria & .. & . & . & .. & . & & \\
\hline Virus Inclus & ions & .. & . & . & . & 18 & $3 \cdot 6$ \\
\hline Trichomona & 1 Infec & tions & . & .. & . & 74 & $14 \cdot 8$ \\
\hline Fungal Infe & ctions & .. & . & . & . & 41 & $8 \cdot 2$ \\
\hline Allergy & .. & .. & . & . & . & 6 & $1 \cdot 2$ \\
\hline \multicolumn{4}{|c|}{ Psychosomatic Conditions. . } & .. & .. & 120 & $24 \cdot 0$ \\
\hline \multicolumn{5}{|c|}{ Associated "L"Organisms (P.P.L.O.) } & . & 72 & $14 \cdot 4$ \\
\hline Unknown & .. & . & . & . & $\ldots$ & 83 & $16 \cdot 6$ \\
\hline Total & . & $\ldots$ & $\ldots$ & . & . & 500 & $100 \cdot 0$ \\
\hline
\end{tabular}

It is clear that, in spite of all screening tests, a significant number of cases of urethritis are of unknown origin.

(3) Diversity of Clinical Features.-Widely different clinical forms may be observed, and in some cases genito-urinary, digestive, ocular, rheumatic, or cutaneous manifestations appear as complications. Sometimes the infectious process develops into a generalized "urethro-conjunctivo - synovial syndrome".

Tables II and III (opposite) give data on two widely different types of non-gonococcal urethritis: that due to Trichomonas vaginalis is common, while that due to virus inclusions is rare. 
TABLE II

URETHRITIS DUE TO TRICHOMONAS VAGINALIS IN MALES

\begin{tabular}{|c|c|c|c|c|c|c|}
\hline & \multirow{2}{*}{\multicolumn{3}{|c|}{ Clinical Features }} & \multirow{2}{*}{$\begin{array}{l}\text { Total } \\
\text { Cases }\end{array}$} & \multicolumn{2}{|c|}{$\begin{array}{c}\text { Positive } \\
\text { Cases of } \\
\text { Trichomonal } \\
\text { Infection }\end{array}$} \\
\hline & & & & & No. & $\begin{array}{l}\text { Per } \\
\text { cent. }\end{array}$ \\
\hline $\begin{array}{l}\text { Grade of } \\
\text { Urethritis }\end{array}$ & $\begin{array}{l}\text { Acute } \\
\text { Subacute } \quad .\end{array}$ & $\begin{array}{l}\ldots \\
\cdots\end{array}$ & $\begin{array}{l}\ldots \\
\cdots\end{array}$ & $\begin{array}{r}38 \\
196\end{array}$ & $\begin{array}{r}4 \\
21\end{array}$ & $\begin{array}{l}10 \cdot 5 \\
10 \cdot 7\end{array}$ \\
\hline Discharge & $\begin{array}{l}\text { Purulent Mor } \\
\text { Scanty } \quad . .\end{array}$ & g Drop & $\cdots$ & $\begin{array}{l}526 \\
326\end{array}$ & $\begin{array}{l}56 \\
53\end{array}$ & $\begin{array}{l}10 \cdot 64 \\
16 \cdot 2\end{array}$ \\
\hline $\begin{array}{l}\text { Complica- } \\
\text { tions }\end{array}$ & $\begin{array}{l}\text { Prostatitis .. } \\
\text { Epididymitis } \\
\text { Balanitis .. }\end{array}$ & $\begin{array}{l}\ldots \\
\cdots\end{array}$ & $\begin{array}{l}\ldots \\
\cdots\end{array}$ & $\begin{array}{r}32 \\
5 \\
15\end{array}$ & $\begin{array}{l}8 \\
2 \\
3\end{array}$ & $\begin{array}{l}25 \cdot 0 \\
40 \cdot 0 \\
20 \cdot 0\end{array}$ \\
\hline $\begin{array}{l}\text { Additional } \\
\text { Lesions }\end{array}$ & $\begin{array}{l}\text { Joint Involve } \\
\text { Eye Involvem }\end{array}$ & $\begin{array}{l}\text { nt } \\
\text { t.. }\end{array}$ & $\ldots$ & $\begin{array}{l}99 \\
96\end{array}$ & $\begin{array}{l}4 \\
2\end{array}$ & $\begin{array}{l}4 \cdot 34 \\
2 \cdot 08\end{array}$ \\
\hline Total & . & . & . & 1,333 & 153 & $11 \cdot 4$ \\
\hline
\end{tabular}

TABLE III

URETHRITIS DUE TO VIRUS INCLUSIONS

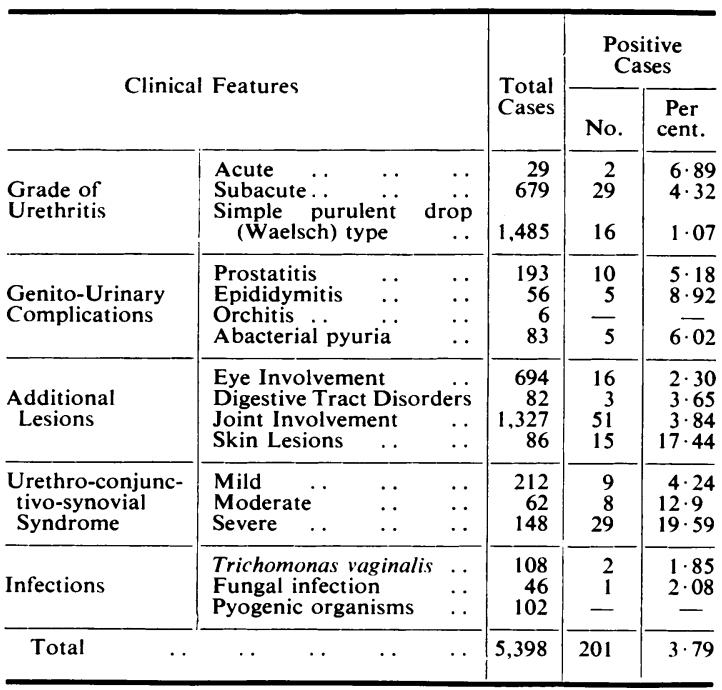

(4) Peculiar Course in Certain Forms of N.G.U.-A "serrated" course may be seen in viral urethritis, in which the relative frequency of relapse usually parallels that of intercourse with untreated contacts.

The poor results of therapy may lead to psychic unbalance.

(5) Malformations.-In many patients suffering from N.G.U., congenital malformations, such as anomalies of the urethral meatus or cicatricial atresias, are observed. These conditions play a large part in creating feelings of sexual inferiority.

\section{Characteristic Psychological Patterns}

In both my private and hospital practice during 1959 , only half of the patients observed appeared to be suitable for psychotherapy. The problem is not simple. While we know very well that genito-urinary disturbances are liable to act upon the psyche, many urethral disorders may be associated with emotional stress without the presence of any microbial, viral, or parasitic cause. The typical reactions may be classified as follows:

(1) Such patients, even if well balanced at the start of the urethral incident, will quickly become unstable and anxious on realizing the potential consequences of their disease to themselves, their families, and their businesses.

N.G.U. often means a long period of disability for the patient. Apart from the severity of some cases, the main danger lies in the great number of obsessions which are liable to develop. Every specialist knows the psychoneurotic who watches his morning discharge, remains reluctant to form or to reestablish a family, doubts his partner's fidelity, and takes large haphazard doses of antibiotics.

The infectious outbreak, although banal in appearance, may be associated with a psychoanalytic complex hidden in the depths of the unconscious. Sadomasochism, narcissism, castration-phobia, and other disorders find in N.G.U. an unexpected somatic support. These anxious patients talk at length about their morning micturition, giving minute details of the painful meatal blocks they experience on waking. Such anxiety is often associated with impotence in men and with frigidity in women. Another much smaller group of patients take a pride in going into details about their past and present urethral episodes, so that an imagined urethritis can be assessed.

(2) At a later stage, because of the persistence and slow evolution of N.G.U., patients may develop a true anxiety melancholia. They are inclined to impute every trouble to their genito-urinary history; they complain of a spreading physical asthenia, and finally believe themselves to be the victims of an incurable disease, such as cancer of the prostate or bladder.

(3) Fear of relapse, the idea of being obliged to refrain for a long period from sexual intercourse, and the fear of being contaminated cause characteristic psychic disturbances which may become mild obsessive syndromes related to phobia.

Ideas of self-reproach are frequent; above all in 
the man who has indulged in an occasional extramarital exposure, for instance during his wife's pregnancy or while on holiday. Feelings of shame and physical incapacity become so acute that some patients go so far as to break up a still-successful marriage and choose to live in solitude. Their business career is also disturbed by their lack of balance and diminished powers of concentration.

(4) Even though the infectious urethritis is cured and the clinical signs have cleared, a purely psychical urethritis may develop, which may be regarded as the reaction of the personality under stress.

Such patients seek medical advice because their urethras are wet, because of urethral or meatal burning, or because of urethro-prostatic pains. The "painful perineo-spermatic syndrome" has been reported by Durel and Siboulet (1959). In such cases the patients were psycho-asthenics focusing their anxiety on the genito-urinary area. The danger lies in the fact that a few patients must be regarded after prolonged and careful examination as serious psychopaths, the abnormal behaviour pattern being masked by the urethral signs. Several cases of attempted suicide are included in Durel and Siboulet's report.

In view of the quite characteristic psychological pattern, which mainly depends upon factors common to the different types of the disease and partly upon the patient's ignorance of these pathological signs, psychotherapy combined with specific treatment is required in most cases.

Such measures should consist above all in restoring the patient's peace of mind and confidence by explaining his genito-urinary condition.

During interviews directed to establishing the "psycho-emotional balance", the family or professional difficulties against which the patient may be struggling should be classified little by little.

Individual psychotherapy alone is not usually sufficient, and in most cases both partners should be interviewed together.

When tests are negative, it is of great importance that no treatment should be prescribed; otherwise the patient may convince himself that he really has a serious pathogenic urethritis. Unfortunately, in many such cases, a range of antibiotics, above all the latest ones, are often needlessly prescribed.

Tranquillizers and sometimes sedatives may be useful, however, and in severe cases, treatment should not be carried out by the urologist alone, but should be planned in collaboration with the psychiatrist.
Incidence of N.G.U.

The increasing frequency of N.G.U. has been noticed in nearly every country. The incidence in 6,000 cases of male urethritis observed within the last 5 years is shown in Table IV.

TABLE IV

CAUSE OF URETHRITIS IN 6,000 MALE CASES

\begin{tabular}{|c|c|c|}
\hline Type of Urethritis & Number & Per cent. \\
\hline $\begin{array}{lllll}\text { Gonococcal .. } & \ldots & \ldots & \ldots & \ldots \\
\text { Non-Gonococcal } & \ldots & & \\
\text { Insignificant Discharge } & \text { and } & \text { Ürethrophobia }\end{array}$ & $\begin{array}{r}886 \\
3,912 \\
1,202\end{array}$ & $\begin{array}{l}14 \cdot 76 \\
65 \cdot 2 \\
20 \cdot 03\end{array}$ \\
\hline
\end{tabular}

The ever-growing number of cases may be related to changes in sexual behaviour, but is also partly due to technical advances which are making diagnosis progressively easier.

A new type of "free" prostitution is competing with the classical form. This makes it easier for men to find sexual consorts, and it is well known that such exposure without payment is often more hazardous.

We are also encountering many more cases of infectious N.G.U. in homosexuals. This is a new feature in France, but it should not surprise us, because the incidence of syphilis and gonorrhoea in homosexuals has also been increasing for the last 5 or 6 years. According to our own statistics 5 per cent. of cases of N.G.U. occurred in homosexuals in 1958.

Too often, an epidemiological study is carried out only in cases of gonorrhoea. Table $\mathrm{V}$ shows the results of an epidemiological inquiry in cases of virus urethritis and trichomonal urethritis.

TABLE V

EPIDEMIOLOGY OF NON-GONOCOCCAL URETHRITIS IN MALES

\begin{tabular}{|c|c|c|c|c|c|c|}
\hline \multirow{2}{*}{$\begin{array}{l}\text { Type of } \\
\text { Urethritis }\end{array}$} & \multicolumn{2}{|c|}{ Exposure } & \multirow{2}{*}{$\begin{array}{l}\text { With } \\
\text { Prosti- } \\
\text { tutes }\end{array}$} & \multirow{2}{*}{$\begin{array}{l}\text { With } \\
\text { Homo- } \\
\text { sexuals }\end{array}$} & \multirow{2}{*}{$\begin{array}{l}\text { Non- } \\
\text { Venereal } \\
\text { Infec- } \\
\text { tions }\end{array}$} & \multirow{2}{*}{$\begin{array}{c}\text { Origin } \\
\text { not } \\
\text { Estab- } \\
\text { lished }\end{array}$} \\
\hline & $\underset{\text { tal }}{\text { Mari- }}$ & $\begin{array}{l}\text { Extra- } \\
\text { marital }\end{array}$ & & & & \\
\hline Viral & 16 & 45 & 12 & 7 & 0 & 30 \\
\hline Trichomonal & 28 & 81 & 20 & 11 & 4 & 6 \\
\hline
\end{tabular}

\section{Conclusions}

The stress of modern living and the peculiar course of many cases of N.G.U. result in a great variety of psychiatric disorders (mostly of the depressive type). Our data suggest the need for treatment with a combination of psychotherapy 
with specific therapy, and demonstrate that psychiatric advice is necessary in many cases. Of all the bodily systems, the genito-urinary is the most susceptible to psychiatric influences: pathological conditions may have an adverse effect upon the mind, and mental disorders may produce genitourinary symptoms. Widely different emotional factors, family conflicts, marital or extra-marital troubles, emotional stress, homosexual tendencies and other perversions, and even occupational difficulties, may act upon the genito-urinary system and start or maintain a psychosomatic urethritis.

Some forms of N.G.U. are infectious and these must be considered as venereal diseases. To control these "new venereal diseases" we have first to bring the partners to be treated at the same time. A frank explanation of the various features of N.G.U. is often enough to relieve the patient's mind and promote a cure.

\section{Summary}

N.G.U. has certain particular features: the onset; the diversity of causes (in spite of advances in diagnosis the cause of over 16 per cent. remains unknown); the variety of clinical features; the frequency of relapses and failures of treatment. These features may account for the characteristic psychological pattern seen in patients with this disorder. More than 50 per cent. of such patients require psychotherapy. They soon become anxious and unstable, cases of true anxiety melancholia occur, and psychic disturbances associated with individual, familial, or occupational problems are frequent. The ever-increasing incidence of N.G.U. (this was the diagnosis in $68 \cdot 2$ per cent. of 6,000 male cases of urethritis seen by the author) may be partly due to changed sexual behaviour, and there has also been a marked increase in N.G.U. in homosexuals.

\section{REFERENCES}

Collier, L. H. (1959). Brit. med. Bull., 15, No. 3, 231.

Durel, P., and Siboulet, A. (1959). In "Traitement des suppurations urétro-génitales et de leurs complications chez l'homme et chez uretro-genitales et de leurs compl

Jones, B. R., Collier, L. H., and Smith, C. (1959), Lancet, $1,902$.

Aspects psychologiques particuliers des malades atteints d'urétrite non-gonococcique

Résumé

Un certain nombre de facteurs propres aux urétrites non-gonococciques-circonstances d'apparition, diversité étiologique (et malgré le perfectionnement des techniques de recherche, plus de 16 pour cent d'U.N.G. restent d'étiologie inconnue), diversité des tableaux cliniques, fréquence des récidives, efficacité parfois mediocre des traitements proposés, tout cela provoque des aspects psychologiques bien particuliers chez les porteurs de ces types d'urétrites. Plus de 50 pour cent des malades sont justiciables d'un traitement psychothérapique; les malades deviennent vite des auxieux, des instables; certains font même une véritable mélancolie anxieuse, les troubles psycho-caracteriels retentissent sur la vie familiale et professionnelle.

Le nombre de plus en plus grand des cas de U.N.G. (sur 6,000 cas d'urétrites masculines, l'auteur a relevé $65 \cdot 2$ pour cent d'U.N.G.) peut s'expliquer en partie par les changements survenus dans le comportement sexuel des individus. Il faut aussi souligner l'augmentation des cas d'U.N.G. chez les homosexuels. 